\title{
遺伝的アルゴリズムとガウス近似を用いた等色関数の補正法
}

\section{Correction Method of Color-Matching Functions Using Genetic Algorithm and Gaussian Approximation}

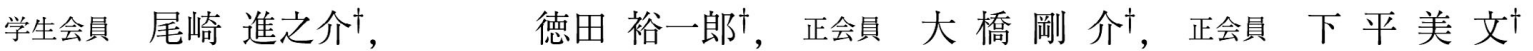

Shinnosuke Ozaki ${ }^{\dagger}$, Yuichiro Tokuda ${ }^{\dagger}$, Gosuke Ohashi ${ }^{\dagger}$ and Yoshifumi Shimodaira ${ }^{\dagger}$

\begin{abstract}
Spectrocolorimeters are widely used to adjust the color of items such as LCDs, CRTs, projectors, and other video equipment. However, the color appearance of one display is sometimes mismatched with that of another display, even though the colorimetric values of the two - which are measured at the same time and under the same illumination - have been matched. It has been reported that the gap between color-matching functions and the human perception of color causes this phenomenon. The purpose of this study was to correct color-matching functions to reduce the gap between colorimetric values and human perception of color. Color-matching functions were approximated by Gaussian functions, which were controlled by ten parameters. The parameters were optimized using genetic algorithm to minimize color differences between the colorimetric values of the supervised data. Results show that the perceptual color matching was improved.
\end{abstract}

キーワード：遺伝的アルゴリズム，ガウス近似，等色関数，知覚的カラーマッチング

\section{1. まえがき}

現在，液晶ディスプレイ，CRT，プロジェクタなどのさ まざまな映像機器が普及し, 表示性能は飛躍的に向上して いる。それに伴い，ユーザの色の表示に関する関心が高ま り，より高精度な色表示が求められている。現在の映像機 器の色調整には，色を定量的に数值で表現する測色計が用 いられている．測色計の中でも精度が高い分光放射輝度計 は，図 1 のように，分光分布と呼ばれる可視領域内の各波 長のエネルギーを測定し，CIEにより 1931 年に提案され ている等色関数を介して，(1) 式のように測色值を算出し ている ${ }^{1) \sim 3)}$.

$$
\left.\begin{array}{l}
X=k \int_{v i s} C(\lambda) \cdot \bar{x}(\lambda) \\
Y=k \int_{v i s} C(\lambda) \cdot \bar{y}(\lambda) \\
Z=k \int_{v i s} C(\lambda) \cdot \bar{z}(\lambda)
\end{array}\right\}
$$

ここで，式 (1) において，積分範井は可視波長域， $k$ は正 規化のための定数, $C(\lambda)$ は分光分布, $\bar{x}(\lambda), \bar{y}(\lambda), \bar{z}(\lambda)$ はそれぞれ等色関数を表している。

\section{8 年 12 月 4 日, IDW'08 で発表}

2009 年 3 月 4 日受付, 2009 年 6 月 24 日再受付, 2009 年 7 月 21 日採録 †静岡大学 工学部

( $\bar{T}$ 432-8561 静岡県浜松市中区城北 3-5-1,TEL 053-478-1110)

$\dagger$ Faculty of Engineering, Shizuoka University

(3-5-1, Johoku, Naka-ku,Hamamatsu, Shizuoka 432-8561, Japan)

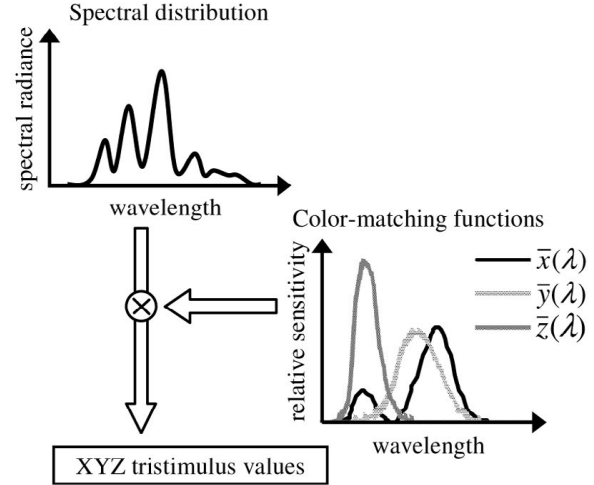

図 1 測色值の算出方法

Calculation method of colorimetric values.

等色関数は，CIEにより 1931 年に 2 度視野，1964 年に 10 度視野に対応するものが提案されており，人間の目の分 光感度を示すものとして広く一般的に用いられている。

2 度視野等色関数は, CIE 測色標準観測者に完全に一致 するような等色関数であり，複数の被験者による 2 度視野 での等色実験の結果に基づいて制定された。10度視野等色 関数は, CIE 測色補助標準観測者に完全に一致する等色関 数であり，複数の被験者による 10 度視野での等色実験の 結果に基づて制定された。しかし，等色実験は欧米で行 われており，日本人の等色関数は現在の等色関数と誤差が 生じていること ${ }^{4)}$ や，標準観測者は実際には存在せず，人 それぞれの等色関数は個人差が生じていることが問題とさ れている ${ }^{5)}$ ，そして，欧米人と日本人の差や，個人差の問 
題のほかに，文献 6) では，CRTディスプレイと色票にお ける知覚的カラーマッチング不一致について調査し, 等色 関数の個人差によりばらつく色もあるが，全被験者におい て同じ方向へとずれる色もあることから，標準観測者の等 色関数に補正が必要であるとしている。また，2台の液晶 ディスプレイの測色值が等しいにもかかわらず，2台のディ スプレイ間の色の見えが一致しない現象や，同様に，2台 のディスプレイ間の色の見えが一致した場合にも，2台の ディスプレイの測色值は異なってしまうという現象も起こ ることがあり, 液晶ディスプレイにおいても等色関数と人 間の視覚との間のずれにより, 知覚的カラーマッチング不 一致の現象が生じる場合がある。

そこで本論文では, 等色関数と人間の視覚との間のずれ を軽減するように等色関数を補正し, 液晶デイスプレイに おける知覚的カラーマッチング不一致の現象を軽減するこ とを目的とする。ただし，等色実験の結果から制定されて いる等色関数は, 数式で表現されておらず, 各波長の值が規 定されているのみであり，可視波長域内のすべての值を補 正することは困難である。そこで本手法では，ガウス関数 を用いて等色関数をガウス近似することにより, 等色関数 を数個のパラメータで制御する。そして，ガウス近似した 等色関数のパラメータを適切に最適化することにより, 等 色関数の補正を行う。パラメータの最適化においては，大 域的探索に優れ, 最適化問題に対して有効な解法であると されている遺伝的アルゴリズムを用いる。

\section{2. 等色関数の補正方法}

\section{1 概 要}

本手法では, 2 台のディスプレイの XYZ 三刺激值が等し いとき, 知覚的カラーマッチングが実現するように等色関 数を補正する。 このとき, 2 台のディスプレイは, 同一環 境のもと, 同時に観察されているものとする. 本手法では, 図 2 に示すように, ディスプレイ 1 とディスプレイ 2 にお ける，色の見えが一致しているがXYZ 三刺激值が不一致 である分光分布の組を学習データとして用い, 学習データ 内の複数のディスプレイ間の色差が小さくなるように, 等 色関数を補正する. 本手法では, 等色関数の補正の際, 等 色関数をパラメータで制御するため, ガウス関数で近似し, ガウス関数のパラメータを, 遺伝的アルゴリズムを用いて 最適化することで，等色関数の補正を行う。

\section{2 ガウス関数による等色関数の近似}

文献 7) では, 撮像装置の分光感度をガウス関数で近似し, 分光感度を推定している. ガウス関数は, 3 個のパラメー 夕で簡単に制御できるため, 一つのピークを持つ関数はガ ウス近似することがある。そこで本手法では, 等色関数を パラメータで制御するため, ガウス関数で近似し, 補正を 行う. 現行の等色関数は, $\bar{x}(\lambda), \bar{y}(\lambda), \bar{z}(\lambda)$ の三種類の曲 線であり, それぞれについてピークが 2 個, 1 個, 1 個存在 しているため, 合計で 4 個のピークが存在する。 そこで本

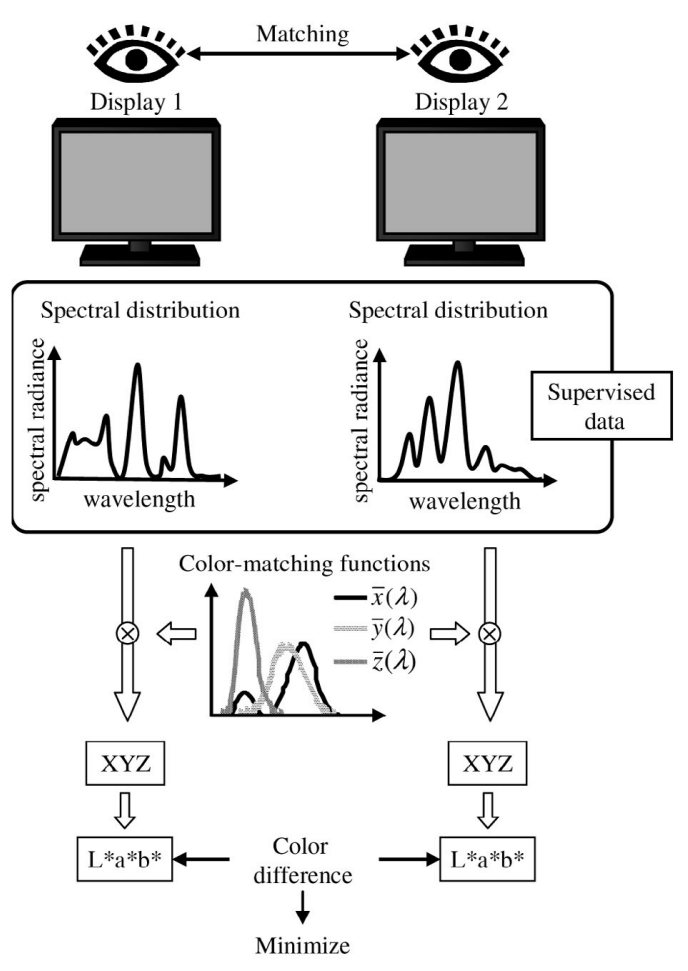

図 2 本手法の概観

Overview of the proposed method.

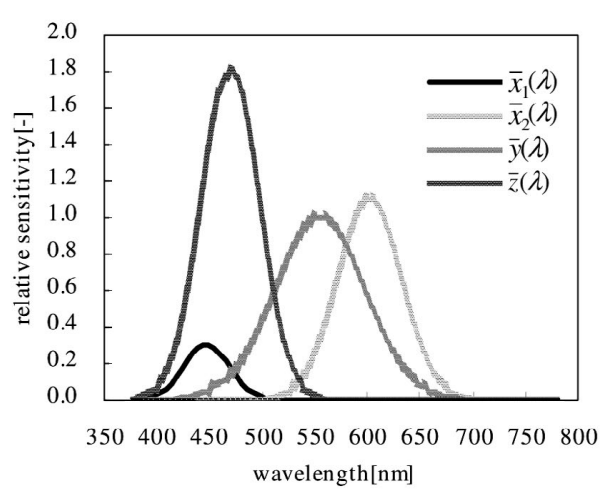

図 3 ガウス近似された等色関数

Color-matching functions approximated by Gaussian functions.

手法では，図 3 に示すように，等色関数を 4 個のガウス関 数で近似する。図 3 において, 横軸は波長, 縦軸は相対感 度を示している.ピークが 2 個存在している等色関数 $\bar{x}(\lambda)$ を 2 個のガウス関数 $\bar{x}_{1}(\lambda)$ と $\bar{x}_{2}(\lambda)$ の和で表現し, ピーク が 1 個存在している等色関数 $\bar{y}(\lambda)$ と等色関数 $\bar{z}(\lambda)$ はそれ ぞれ $\bar{y}(\lambda)$ と $\bar{z}(\lambda)$ でガウス近似している.

ガウス関数のパラメータについて，図４にそそれそれのガ ウス近似した等色関数 $\bar{x}(\lambda), \bar{y}(\lambda), \bar{z}(\lambda)$ を制御するパラ メータを示す。ここで, 忷 4 における横軸は波長, 縦軸は 相対感度を示している. 1 個のガウス関数に対して 3 個の パラメータで制御するため，4 個のガウス関数では合計 12 個のパラメータが必要であるが, 本手法では, パラメータ の軽減を実現し，4個のガウス関数を合計 10 個のパラメー タで制御している。

ガウス関数のパラメータは, 中心波長の值, 相対感度の 


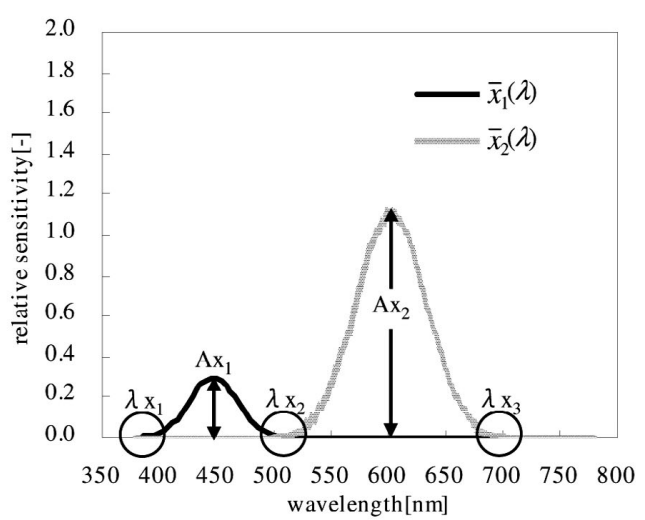

(a) Color-matching function $\bar{x}(\lambda)$

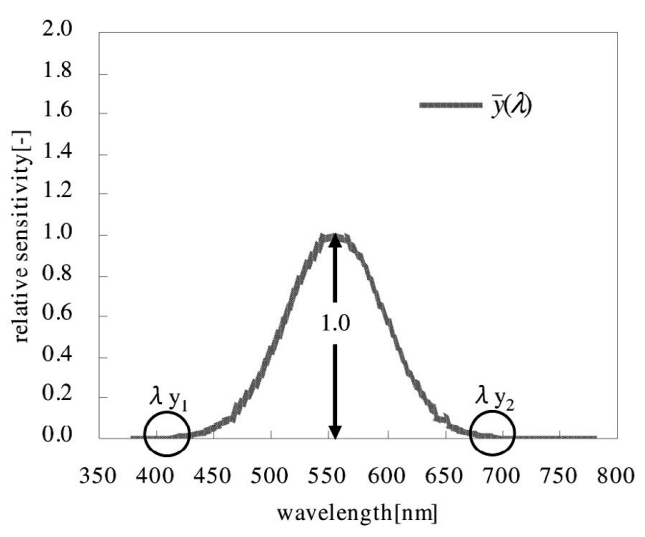

(b) Color-matching function $\bar{y}(\lambda)$

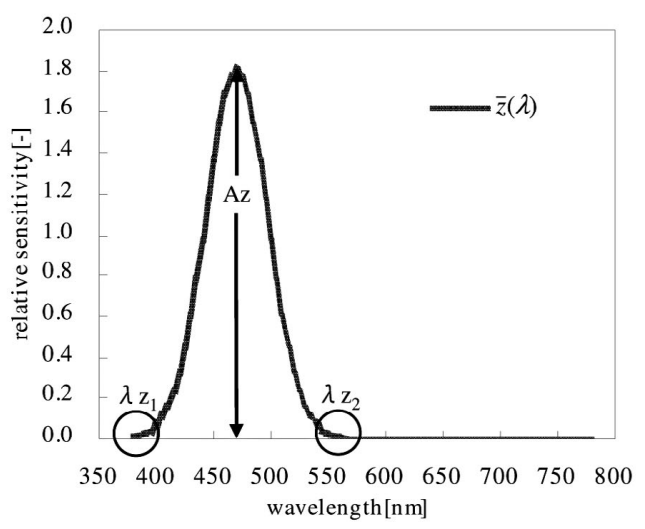

(c) Color-matching function $\bar{z}(\lambda)$

図 4 ガウス近似された等色関数のパラメータ

Parameters of color-matching functions approximated by Gaussian functions.

大きさ，半值幅の 3 個が一般的であるが，本手法では，効 率的に等色関数を制御するため, ガウス関数の 3 個のパラ メー夕は，相対感度の大きさであるパラメー夕，および相 対感度がほぼ 0 となる $e^{-5} \fallingdotseq 0$ のときの波長の值である 2 個のパラメータとしている。

等色関数 $\bar{x}(\lambda)$ は, 2 個のガウス関数 $\bar{x}_{1}(\lambda)$ と $\bar{x}_{2}(\lambda)$ の和 で表現しており, 図 4(a) のように, 相対感度の大きさを表 すパラメータをそれぞれ $A x_{1}, A x_{2}$ とし,$x_{1}(\lambda)$ と $x_{2}(\lambda)$ が重なるところを 1 個のパラメータ $\lambda x_{2}$ で表現することに より，波長の值を表すパラメータは， $\lambda x_{1}, \lambda x_{2}, \lambda x_{3}$ で表 現する. 以上より, 等色関数 $\bar{x}(\lambda)$ は, 合計 5 個のパラメー タで制御することができる。
表 110 個のパラメータの定義域

Domain of ten parameters.

\begin{tabular}{l|c|c}
\hline \hline \multirow{2}{*}{$\begin{array}{l}\text { Parameters of } \\
\text { amplitude }\end{array}$} & $A x_{1}$ & $1.02 \sim 1.17$ \\
\cline { 2 - 3 } & $A x_{2}$ & $0.22 \sim 0.37$ \\
\cline { 2 - 3 } & $A z$ & $1.72 \sim 1.87$ \\
\hline \hline \multirow{3}{*}{ Parameters of } & $\lambda x_{1}$ & $692 \sim 707$ \\
\cline { 2 - 3 } & $\lambda x_{2}$ & $497 \sim 512$ \\
\cline { 2 - 3 } & $\lambda x_{3}$ & $382 \sim 397$ \\
\cline { 2 - 3 } & $\lambda y_{1}$ & $682 \sim 697$ \\
\cline { 2 - 3 } & $\lambda y_{2}$ & $412 \sim 427$ \\
\cline { 2 - 3 } & $\lambda z_{1}$ & $552 \sim 567$ \\
\cline { 2 - 3 } & $\lambda z_{2}$ & $372 \sim 387$ \\
\hline
\end{tabular}

そして，等色関数 $\bar{y}(\lambda)$ について，図 4(b) のようなパラ メータで制御する。等色関数 $\bar{y}(\lambda)$ は最大值が 1.0 に正規化 されているため, 本手法では, 等色関数 $\bar{y}(\lambda)$ の相対感度の 大きさは常に 1.0 としている. そのため, 等色関数 $\bar{y}(\lambda)$ は, 波長を表す 2 個のパラメータ $\lambda y_{1}, \lambda y_{2}$ で制御している.

等色関数 $\bar{z}(\lambda)$ は, 図 4(c) に示すように, パラメータ $A z$, パラメータ $\lambda z_{1}, \lambda z_{2}$ の 3 個のパラメータで制御する. 以 上より，4 個のガウス関数は 10 個のパラメータにより表現 可能であり，これらのパラメータを適切に最適化すること によって等色関数を補正することができる.

\section{3 遺伝的アルゴリズムを用いた等色関数のパラメー タの最適化}

本手法では，10 個のパラメータを学習デー夕に基づいて 最適化するため, 大域的探索に優れた遺伝的アルゴリズム を用いる．遺伝的アルゴリズムは他の最適化問題の解法で 必要とされる可微分性, 単峰性などの制約条件を必要とし ないという性質をもち, 最適化問題に対して有効な解法で あるとされている。遺伝的アルゴリズムは，生物進化の原 理に着想を得たアルゴリズムであり, 確率的探索の一手法 である ${ }^{8)}$. 遺伝的アルゴリズムでは，各探索点を個体と呼 び，その個体は一般的に 0 と 1 のビット列からなる染色体 をもっている．また，各個体は適応度と呼ばれる評価值に より評価され，適応度に基づき選択される，選択された個 体に対して交叉・突然変異の処理が行われ, 新たな個体が 生成される，選択されなかった個体は淘汰される，適応度 が大きい個体ほど次世代に残りやすくなり，逆に小さいほ ど淘汰されやすくなる，進化の過程のようにその処理を重 ねていくことで効率よく解を探索することができる.

本手法では，ガウス関数を制御する 10 個のパラメータに ついての最適化問題を遺伝的アルゴリズムに導入するため, 10 個のパラメータをそれぞれ 4 ビット, 計 40 ビットの染 色体に遺伝子コーディングしている. 10 個のパラメータの 定義域は，現行の等色関数の形状の変化を最低限にするこ とを考慮し，予備実験の結果より表 1 のように決定した。

遺伝的アルゴリズムを用いた本手法のフローチャートを 図 5 に示す。本手法では，まず「個体集合の初期化」を行 う。個体集合の初期化では, 収束精度, 収束時間を考慮し 50 個の個体を生成する。一般に, 遺伝的アルゴリズムの初 


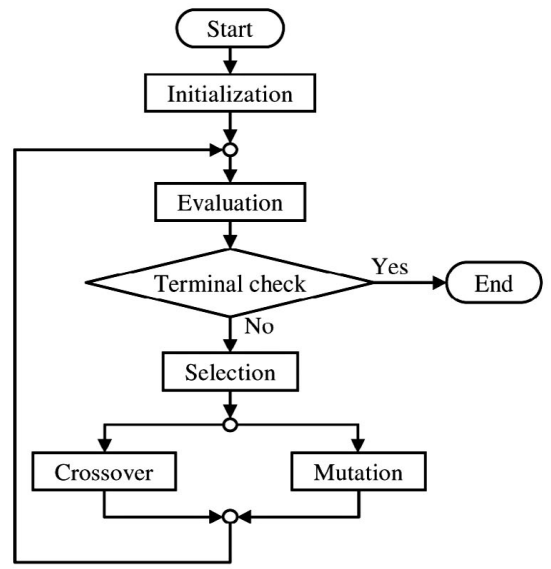

図 5 本手法のフローチャート

Flowchart of the proposed method.

表 2 本手法の遺伝的アルゴリズムパラメータ

Genetic Algorithm parameters of this technique.

\begin{tabular}{c|c|c}
\hline \hline Process & Method & Probability \\
\hline \hline Sclection & Roulcttc whecl sclection & Elitist preserve stratcgy; 2\% \\
\hline Crossover & Uniform crossover & $93 \%$ \\
\hline Mutation & Reversal & $5 \%$ \\
\hline
\end{tabular}

期化では，解空間は分割しないが，本手法では，局所的最 適解に陥らないようにするため, 10 個のパラメー夕により 表現される解空間を等分割し，それぞれの領域内で個体を ランダムに生成し，生成した個体に対応する等色関数を作 成する，次に，生成した個体を「評価」する，各個体に対 応する等色関を数をいて, 学習データの分光分布から XYZ 三刺激値を算出し， $\mathrm{L}^{*} \mathrm{a} * \mathrm{~b} *$ 色空間へ変換した後，色差を計 算し，その平均色差を適応度として用いる。ただ，本手 法において，色差の算出に人間の視覚による色の見えによ る色差の評価と近いものとして提案されている CIE2000 色 差式 9）を用いている。 また, CIE2000 色差式の算出の際, パラメトリック係数 $k_{L}, k_{C}, k_{H}$ については, 本実験は, 標準環境であるので, $k_{L}=k_{C}=k_{H}=1.0$ としている. 色差 が小さくなった個体に相当する等色関数は適応度が高くな り, 優秀な個体と評価する.「終了判定」では，世代数が閥 值を超えているか否かで判定を行う。閾值は, 予備実験の 結果より, 収束精度を考慮し, 1000 世代とする。閾値を超 えた場合には終了し，超えていない場合には，次の処理に 移る。そして，適応度に応じて各個体を「選択」する。選 択方法は, 遺伝的アルゴリズムで最も一般的に用いられて いるルーレット選択を用いる。 その後, 遺伝的アルゴリズ ムオペレータにより処理を行う。「選択」にて選択した個体 に対応した染色体を一定の確率で「交叉」または「突然変 異」し，次世代の個体を生成する，本手法では，交叉は一 様交叉, 突然変異は反転を用いている。遺伝的アルゴリズ ムのパラメー夕は収束時間の短縮，収束精度の向上を考慮 して，予備実験の結果により表 2 のように決定した。
表 3 本手法による等色関数と CIE1931 の等色関数の記号

Symbols of color-matching functions of this tequniue and CIE1931 Color-matching functions.

\begin{tabular}{l||c|c|c|c||c}
\hline \hline \multicolumn{1}{l||}{} & \multicolumn{4}{c||}{ This technique } & Current \\
\hline \hline $\begin{array}{l}\text { Color-matching } \\
\text { functions }\end{array}$ & $F_{A-B}$ & $F_{B-C}$ & $F_{C-A}$ & $F_{A-B-C}$ & $F_{C I E 1931}$ \\
\hline Supervised data & $\mathrm{A}-\mathrm{B}$ & $\mathrm{B}-\mathrm{C}$ & $\mathrm{C}-\mathrm{A}$ & $\mathrm{A}-\mathrm{B}-\mathrm{C}$ & - \\
\hline
\end{tabular}

\section{3. 実 験}

\section{1 等色関数の補正}

実験は暗室にて，3台のディスプレイ $\mathrm{A} ， \mathrm{~B} ， \mathrm{C}$ を用いて 行った。視野角は 2 度となるように, ディスプレイにカバー をかけて視野角を調節した。 まず学習データの取得を行っ た．基準とするデイスプレイ A に，マクベスカラーチャー トの 1 番の色を全画面表示させ, ディスプレイ $\mathrm{B}$ および ディスプレイ C の表示色がディスプレイ A の色の見えと 等しくなるように，ディスプレイ $\mathrm{B}$ とディスプレイ C の RGB 階調值を調整した，その後，分光放射輝度計を用い て学習データであるディスプレイ A， B，Cの表示色の分 光分布を取得した．同様に，マクベスカラーチャート 2 番 から 24 番においても，学習データであるディスプレイ A, $\mathrm{B}, \mathrm{C}$ の色の見えが等しい色の分光分布を取得した.

次に，デイスプレイ A-B 間， B-C 問，C-A 間，A-B-C 間それぞれの学習デー夕を用いて, 本手法による等色関数 $F_{A-B}, F_{B-C}, F_{C-A}, F_{A-B-C}$ を導出した. 本手法によ る等色関数と CIE1931 の等色関数の記号を表 3 に示す.

\section{2 検証実験方法}

図6に示すように，まず，被験者はデイスプレイ A を基準 とし，ディスプレイBの色の見えが一致するように，RGB 階調值を調整する。そして，このときディスプレイ A， B の分光分布に対し, 本手法による等色関数 $F_{A-B}, F_{B-C}$, $F_{C-A}, F_{A-B-C}$ およびCIE1931 の等色関数 $F_{C I E 1931}$ を 用いて, XYZ 三刺激值を算出し, $\mathrm{L}^{*} \mathrm{a} * \mathrm{~b} *$ 色空閒へ変換し た後，CIE2000 色差式を用いて色差を算出し，比較する。 色差が小さくなった等色関数は, 知覚的カラーマッチング 不一致の現象が軽減しているということになる。被験者 5 名に対し, マクベスカラーチャートの 1 番から 24 番の色 を対象とした. ディスプレイはディスプレイ $\mathrm{A}, \mathrm{B}, \mathrm{C} の 3$ 種類を用い，ディスプレイ A-B 間， B-C 間， C-A 間に対 して実験を行った。

\section{3 検証実験結果}

図 7 にそれぞれの等色関数を用いて算出した 24 色の平 均色差を示す．敦７はそれぞれのディスプレイ間における 平均色差を示しており, 横軸は比較したディスプレイ, 縦 軸は平均色差を示している。図 7 より, デイスプレイ A-B 間，B-C 間，C-A 間すべてにおいて，CIE1931 の等色関数 $F_{C I E 1931}$ に比べ，本手法による等色関数 $F_{A-B}, F_{B-C}$, $F_{C-A}, F_{A-B-C}$ は平均色差が小さくなっており, CIE1931 の等色関数よりも，本于法による等色関数を用いた方が，知 


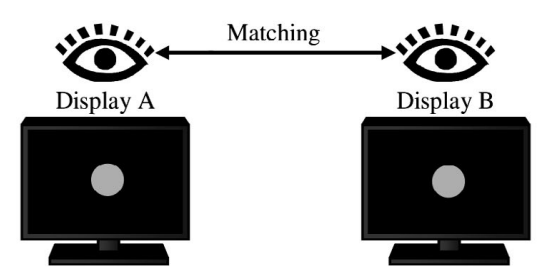

Spectral distribution

Spectral distribution
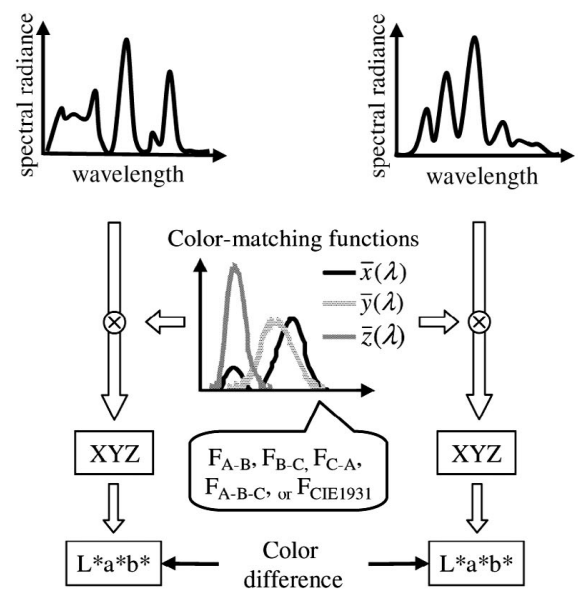

図 6 検証実験の概観

Overview of the verification experiments.

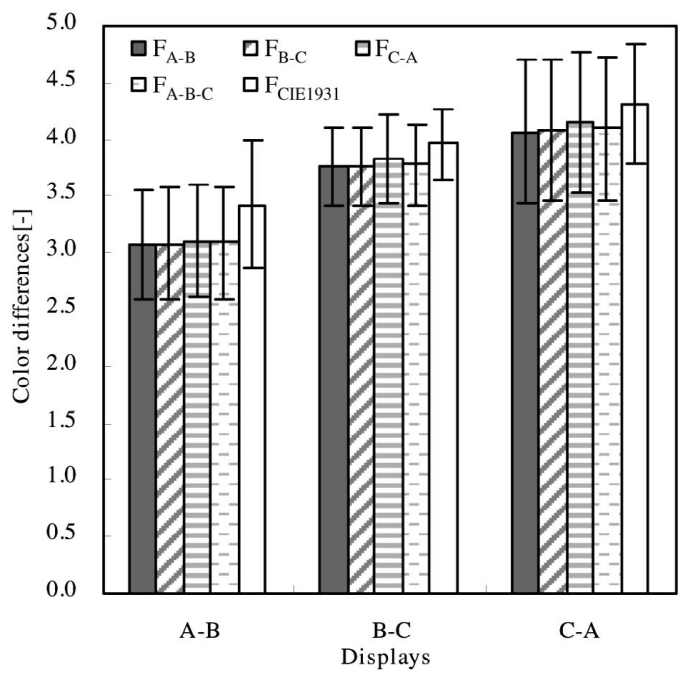

図 7 各デイスプレイ間の平均色差の比較 Comparison with average color differences between displays.

覚的カラーマッチング不一致の現象が軽減することがわかる.

次に, 図 8 にマクベスカラーチャートの色ごとの色差の 比較を示す.ここで, 図 8 の横軸は色差, 縦軸の数值はマク ベスカラーチャートに扔ける色番号に対応して㧍り，Avg. は 24 色の平均を示している. 本手法は, 24 色の平均色差 を下げるように等色関数を最適化しているため, CIE1931 の等色関数で色差が大きかった 17 番から 24 番（Magenta, Cyan, White, Neutral 8, Neutral 6.5, Neutral 5, Neutral 3.5, Black）において, 色差が大きく減少し, CIE1931 の等色関数で色差の小さかった 2 番, 8 番, 10 番 (Light Skin, Purplish Blue, Purple) は, 色差が増加した. 平均

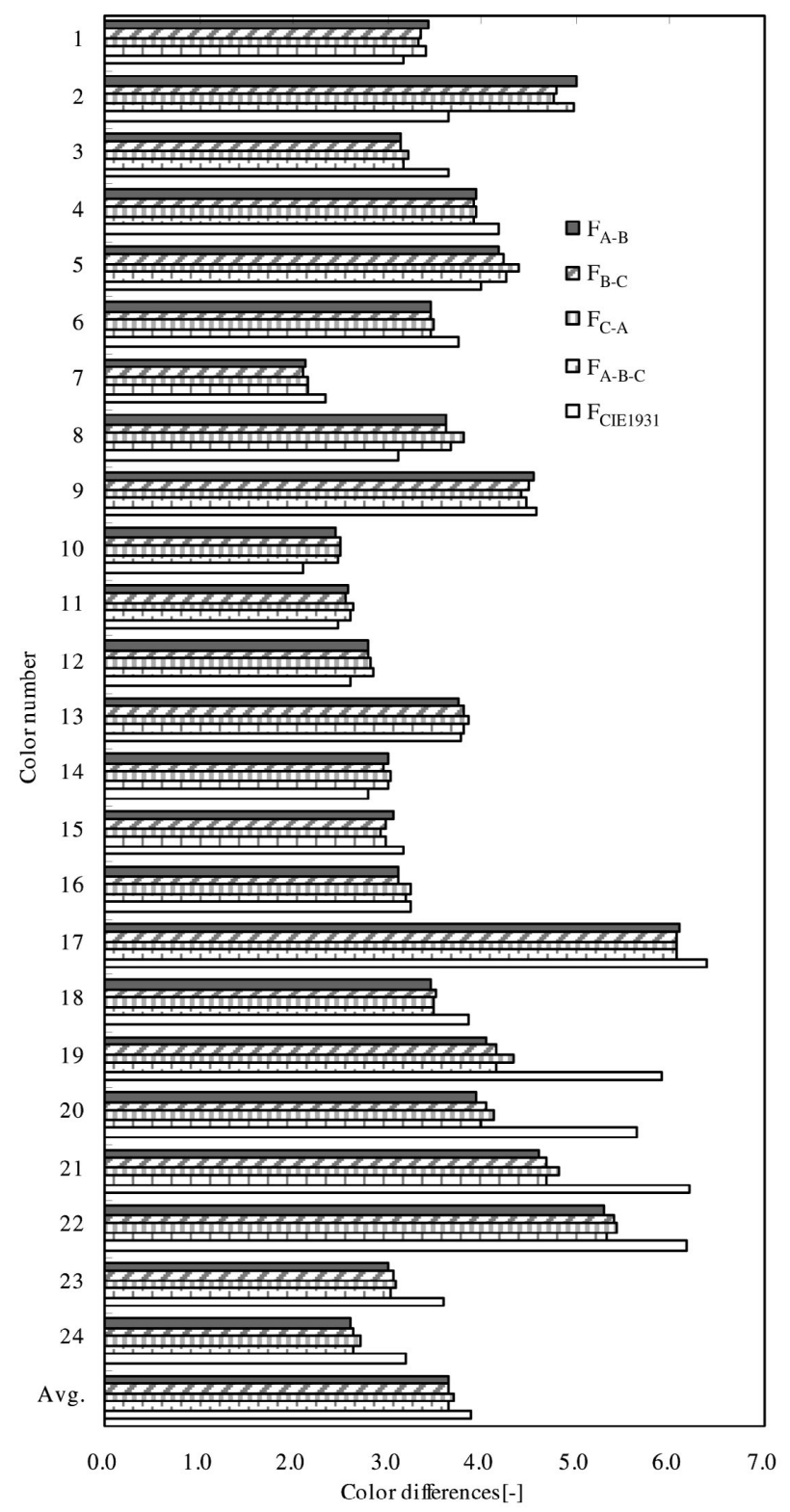

図 8 各色の色差の比較 Comparison with color differences of colors.

色差に関しては, CIE1931 の等色関数よりも本手法による 等色関数の方が小さくなており，本手法による等色関数 を用いると，知覚的カラーマッチング不一致の現象が軽減 していることが確認できる。

\section{4 考 察}

等色関数をガウス関数で近似することに対して考察する. 現行の等色関数は，等色実験の結果に基づいて制定されて おり，等色関数をガウス関数で近似してもよいということ は確立されていない，本研究では，色差を評価関数として， 遺伝的アルゴリズムを用いて等色関数を補正するため，ガウ ス近似を用いて等色関数をパラメータで表現した．図 9 に， それぞれディスプレイ A-B 間，B-C 間，C-A 間，A-B-C 間に㧍ける，CIE1931 の等色関数，CIE1931 の等色関数 をガウス近似したもの，本手法において補正を行った等色 関数を用いて算出した 24 色の学習データの平均色差を示 


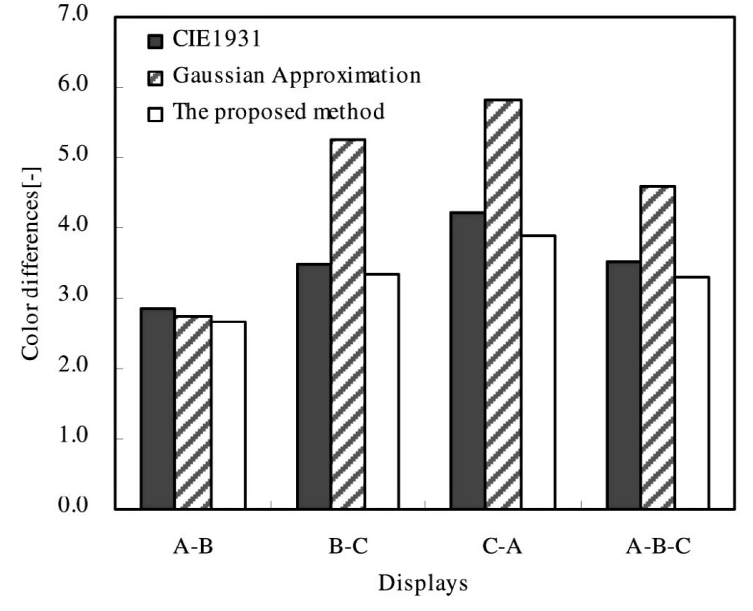

図 9 それぞれの等色関数に扔ける学習デー夕の平均色差 Average color differences of supervised data of each colormatching functions.

す。ただし，図 9 の横軸は比較したそれぞれのディスプレ イ, 縦軸は平均色差を示している. 図 9 より, ディスプレ イ A-B 間では，ガウス近似により色差が小さくなっている が，その他では CIE1931 の等色関数をガウス近似すること により，色差が大きくなっている，しかし，本手法による 補正の効果により，色差が小さくなっていることがわかる. したがって, 補正した等色関数を用いることにより, 液晶 ディスプレイの知覚的カラーマッチング不一致の現象を軽 減していると考えられる。

\section{4. むすび}

本論文では，ガウス近似と遺伝的アルゴリズムを用いて， 知覚的カラーマッチング不一致の現象が生じないような等 色関数を導出した。本手法では，等色関数をパラメータで 制御するため， 4 個のガウス関数で近似し，合計 10 個のパ ラメータで等色関数を制御した．そして，色の見えが等し い分光分仰を学習データとして用い，遺伝的アルゴリズム を用いて 10 個のパラメータを最適化することで, 等色関 数の補正を行った．本手法の有効性を確認するため，色の 見えの等しい色の色差について比較したところ，本手法に よる等色関数を用いた場合, CIE1931 の等色関数を用いた 場合よりも色差が小さくなり，知覚的カラーマッチング不 一致の現象が軽減した。また，パラメータ表現を検討する ことにより，さらなる高精度な等色関数の補正の可能性を 示唆した。

\section{〔文献〕}

1) T.Smith, J.Guild: "The C.I.E. colorimetric standards and their use", Transactions of the Optical Society, 33 (3), 73-134 (1931)

2) W.D.Wright: "A re-determination of the trichromatic coefficients of the spectral colours", Transactions of the Optical Society, 30 141-164 (1929)

3) J.Guild: "The Colorimetric Properties of the Spectrum ", Philosophical Transactions of the Royal Society of London, seriesA, 230, pp.149-187 (1931)

4) K.Katori and M.Fuwa: "Color-matching functions of ten Japanese observers", Journal of light and visual environment, 4, 1, pp.9-16
(1980)

5) C.Oleari, "Inter-Observer comparison of Color-matching functions", Color research and application, 24, 3, pp.177-184 (1999)

6) 羽左間歩, 岡嶋克典, 横井健司, 内川惠二, 山口雅浩, 喜多紘一："CRT ディスプレイと色票の知覚, 测色カラーマッチング不一致と等色関数によ る分析”，日本視覚学誌，15，2，pp.97-100 (2003)

7）森木宏明, 中野靖久, 末原憲一郎, 矢野卓雄: ”液晶チューナブルフィル 夕と白黒 CCD カメラを用いた画像色彩計の開発”, 映情学技報, 25, 48, pp.1-5 HIR2001-75 (2001)

8) J.H. Holland, "Adaptation in natural and artificial systems", University of Michigan Press, Ann Arbor, MI (1975)

9) M.R.luo, G.Cui and B.Rigg: "The Development of the CIE 2000 colour-Difference Formula : CIEDE2000", Color research and application, 26, 5, pp.340-350 (2001)

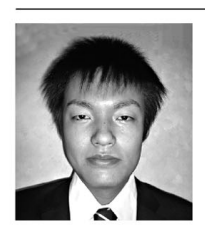

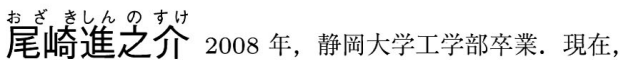
同大大学院修士課程在学中. 視党情報处理に関する研究 に従事. 学生会員.

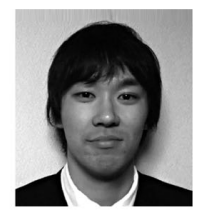

德奋裕いち郎 2007 年, 静岡大学工学部卒業. 2009 年, 同大大学院修士課程修了. 同年, 株式会社日立製作 所に入社. 在学中，対話型進化計算を用いた高画質化支 援システムに関する研究に従事.

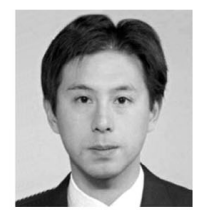

大橋 剛う势介 1992 年, 慶応義塾大学理工学部卒業. 1997 年, 同大学大学院博士課程修了. 同年, 静岡大学工 学部助手. 2004 年, 同助教授. 2007 年，同准教授. 現 在に至る。 2003 年 2004 年, 米国カリフォルニア大学 サンタバーバラ校客員研究員. 主として, 画像処理, 視 営情報処理に関寸る研究に従事. 博士 (工学). 正会員

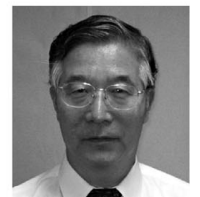

芐だ平 点美文 1972 年, 静岡大学大学院工学研究科 修士課程修了. 1988 年, 博士学位取得（東京大学大学 院）.1990 年，静岡大学工学部助教授。1997 年，同大 学教授. 2006 年, 創造科学技術大学院教授. 主として, 視覚情報処理, 画像品質評価, 広色域画像システムに関 する研究に従事. 正会員. 